University of Wollongong

Research Online

Faculty of Social Sciences - Papers (Archive) Faculty of Arts, Social Sciences \& Humanities

2004

Keeping the faith: The impact of human services restructuring on Catholic social welfare services

Gail Winkworth

Australian Catholic University

Peter J. Camilleri

University of Wollongong, petercam@uow.edu.au

Follow this and additional works at: https://ro.uow.edu.au/sspapers

Part of the Education Commons, and the Social and Behavioral Sciences Commons

Research Online is the open access institutional repository for the University of Wollongong. For further information contact the UOW Library: research-pubs@uow.edu.au 


\title{
Keeping the faith: The impact of human services restructuring on Catholic social welfare services
}

\begin{abstract}
Church related agencies are major providers of community services in Australia (Lyons, 2001:34-35). While the history of church related welfare service provision is not well known in Australia it is asserted that many have a long tradition of outreach and service provision to marginalised groups regardless of the government social policy of the day (ACSWC, 2000; Mendes, 2003). This paper examines the current environment of human services restructuring and the impact of the shift to contractualism on one church related provider: Catholic social welfare provision in Australia. It explores the significance of the church's social teachings and history on concerns that service innovation, diversity and advocacy are currently under threat. Finally it calls for greater appreciation of the distinctive contribution of church related agencies and what they have to offer in service delivery and as contributors to the social policy discourse.
\end{abstract}

\section{Keywords}

catholic, restructuring, keeping, services, welfare, human, faith, impact, social

\section{Disciplines}

Education | Social and Behavioral Sciences

\section{Publication Details}

Winkworth, G. \& Camilleri, P. (2004). Keeping the faith: The impact of human services restructuring on Catholic social welfare services. Australian Journal of Social Issues, 39 (3), 315-328. 


\title{
Keeping the Faith: \\ The Impact of Human Services Restructuring on Catholic Social Welfare Services
}

\author{
Gail Winkworth and Peter Camilleri
}

\begin{abstract}
Church related agencies are major providers of community services in Australia (Lyons, 2001:34-35). While the history of church related welfare service provision is not well known in Australia it is asserted that many have a long tradition of outreach and service provision to marginalised groups regardless of the government social policy of the day (ACSWC, 2000; Mendes, 2003). This paper examines the current environment of human services restructuring and the impact of the shift to contractualism on one church related provider: Catholic social welfare provision in Australia. It explores the significance of the church's social teachings and history on concerns that service innovation, diversity and advocacy are currently under threat. Finally it calls for greater appreciation of the distinctive contribution of church related agencies and what they have to offer in service delivery and as contributors to the social policy discourse.
\end{abstract}

\section{Gail Winkworth \& Peter Camilleri}

Gail Winkworth formerly Lecturer in Social Work at the Australian Catholic University and is currently

Business Manager (Participation Practice and

Development) National Office Centrelink, Canberra

Professor Camilleri is Associate Professor in

Social Work and Rector of the Canberra Campus

(Signadou) of the Australian Catholic University. 


\section{Introduction}

Over the past two decades Australia has undergone a reconstruction in the way it delivers human services with significant changes in responsibility for service provision shifting from the state to the non-government sector. This restructuring included a move away from grants based funding to the purchased provider model including highly specified contractual arrangements in the delivery of services. While non-profits are responding to this shift in diverse ways, many which are church related question the processes involved in the shift and the extent to which it has achieved a more humane and responsive welfare environment (Mendes,2003). Central to this questioning is a contest of values and competing discourses about the responsibility of church groups as service providers and social welfare lobbyists. This paper explores the Catholic Church's long history of care and advocacy and the perceived threat posed by this restructuring to the delivery of humane and responsive services.

\section{Church Related Providers in Australia}

In 1995 according to the Industry Commissions Report on Charitable Services, around 11,000 community social welfare organisations received government funding in Australia. The same report recognised that there were an unknown number of other organisations, which relied entirely on volunteers and private donations to finance their social welfare activities (Industry Commission, 1995:XV11).

The fifty largest of these organisations each had a recurrent annual expenditure of more than $\$ 10 \mathrm{~m}$ and collectively they spent around $\$ 1.6 \mathrm{~b}$ (half of which came from government funding). The top six social welfare providers and 9 of the top 15 providers were church related agencies. ${ }^{1}$ Although Catholic agencies did not appear on this list one report at the time noted that the annual turnover of Catholic human services agencies (including health) exceeded 5 billion dollars. Its paid workforce of at least 130,000 would, it asserted, make it the largest employer of human service personnel after the public sector (Cleary, 1994:52). A recent study conducted by the Australian Catholic University found that Catholic agencies delivered more than 1000 individual social welfare services (excluding health) with an annual expenditure of around half a billion dollars (Camilleri \& Winkworth, 2003).

\section{Restructuring Human Services}

Restructuring of human services in this context refers to fundamental shifts in funding arrangements between government and non-government providers over the past twenty years. It includes the move away from grants based funding to contractual arrangements and an emphasis on improving quality, accountability and value for money.

The rationale for the new arrangements is that it allows government to concentrate on its main roles: legislation, regulation and policy development. Central to this rationale is the belief that non profit agencies, most of whom are church related providers, have a long demonstrated history of delivering innovative, relevant and diverse services more cheaply and effectively than government. Outsourcing, it is thought, also allows clearer service specification, clarity of roles between government and non profit agencies, clearer standards for monitoring performance, higher levels of accountability and a framework for better management (Rogan, 1997: 32). 
There are different views espoused in the literature about the impact of the new arrangements on non-profit providers of welfare services (Wearing, et. al, 1999; Leary, 1994; ASCWC, 2000; Ferguson, 2000; Ife, 1997; Mendes, 2003). A recurring theme is that the language and concepts of restructuring are contentious because they challenge the foundation, traditions and ideology that underpins church related organisations. Ife's framework of competing discourses in human services (Ife, 1997: 56) sheds some light on the nature of the values conflict for non-profit providers. Market and managerial approaches threaten more familiar community focussed and professional frameworks including imbedded notions of service, accountability to the client, and democratic decision-making. In their place is a new language of competition, customer choice, brokerage and entrepreneurism.

A study in 2000 using open-ended interviews of non government service providers and policy and planning bureaucrats from five states and territories identified three broad areas of functioning that are impacted on by the new requirements: autonomy and control; collaboration and partnerships; and infrastructure costs (Neville, 2000). The first, autonomy and control refers to a shift in the balance of power between government and non profits resulting in contractual arrangements which impose changes to the usual client base of an agency and to the kinds of services that are provided. The second, collaboration and partnerships, refers to the reduced capacity of service providers to work together and to be active contributors to government policy in the new competitive tendering environment. Specifically it identified the perceived conflict of interest by Government in talking to service providers who would then compete for contracts. Further, tender processes were seen as leading to a lack of information sharing and general distrust between agencies which had hitherto enjoyed positive collaborative relationships. Finally there was a strongly held view that competitive tendering and purchaser provider models, which are deemed necessary to ensure probity and equity in the distribution of funds to agencies, have led to the channelling of vast resources into processes at the expense of services. The result, the study argued, has been a tendency for efficiency to be placed before quality, resulting in under funding of services (Neville, 2000: 20).

These findings are supported by a recent report on interim findings from a questionnaire of organisations contracted by the Department of Family and Community Services to deliver human services (part of a larger study on government/non government relations). Rawsthorne offers a snapshot of the impact of contractual reporting and accountability requirements on a diverse range of for profit and not for profit providers (Rawsthorne, 2003). Over a quarter of responding organisations said they allocated in excess of eight days in the twenty working days a month to the collection of client data. They attributed this in part to differences in performance reporting requirements of multiple funding sources. Major impacts of increased reporting included: changes to the skills and expertise base of organisations; the introduction of new technology; and the training and retraining of staff. Other impacts included organisational stress attributed to the perception that agencies need to compete rather than collaborate with other providers and a sense that organisations are now more accountable to 'the department' than they are to their various communities. Programs also reported the diversion of resources from their clients and an inability to attract funding for development work. Although the study found that $51.4 \%$ of respondents strongly disagreed that 'mission drift' was a problem 
for them, $41 \%$ reported that the new arrangements were detrimental to innovative and preventive work.

While these studies provide useful insights into the experience of community service providers generally in the current contractual environment, there is a lack of attention to the experience of church related welfare services, particularly the impact on what these agencies regard as their mission. This paper contributes to this understanding by focusing on the experiences in recent years of the largest group of church related providers in Australia: social welfare agencies operating under the auspices of the Catholic Church. Before considering some of the findings from a recent study, "Mapping the Catholic Social Services" (Camilleri \& Winkworth, 2003) it is first useful to establish the importance of social teachings and history to the mission and purpose of Catholic social welfare agencies. This provides us with a better understanding of why the new policy environment is viewed as threatening to the ethos of care and advocacy that is the core of the Catholic tradition.

\section{The Distinctive Ethos Of Care And Advocacy In Catholic Services}

The Social Teachings of the modern Catholic Church, drawn from Canon Law, convey a vision of the church as the servant to humanity, with 'Human beings ... necessarily the foundation, the cause and the end of every social institution' (mater Magistra, 1961; Laborem Exercens, 1981 in Catholic Social Welfare Commission, 2000).

Mendes (2003:157) identifies the core principles as respect for 'individual human dignity', 'promoting the common good', 'solidarity: the responsibility that individuals have for the welfare of one another', the 'universal purpose of goods', the 'preferential option for the poor' and the 'value of work and dignity of workers'. Implicit in these principles is the obligation of the Church based agencies to:

(i) Provide services which promote the inherent dignity of the individual and each individual's participation in family life and community networks

(ii) Provide services which are accessible, particularly to the most disadvantaged in the community

(iii) Speak out publicly so as to improve public policies and programs and identify areas of unmet human need (Australian Catholic Social Welfare Commission, 2000:5)

These principles translate in the social welfare context to an obligation on Catholic agencies to provide humane and responsive services to groups who are disadvantaged regardless of the government policy of the day and a continued public advocacy voice on behalf of the poor and the disadvantaged. These 'substitutive' and advocacy roles enable the provision of a level of care 'beyond the minimum provided by the state' regardless of the political status of issues affecting people in need such as asylum seekers and Indigenous people (ACSWC, 2000:7). Church agencies consider that they bring a practical knowledge base to service delivery, based on direct contact with communities which is often lacking in large bureaucracies (ACSWC, 2000:7).

In contrast to the extensive American literature on 'faith based' agencies (Wuthnow \& Hodgkinson,1990; Cnaan \& Boddie, 2002; Glenn,2000) there are no comprehensive histories of Australian church related agencies on the public record (Camilleri, 2000; 
Graycar, Horsburgh \& Wyndham 1988:358). Much of the historical analysis of social welfare focuses on the development of the Commonwealth social security and industrial relation systems, largely ignoring the vast network of services developed by state governments and voluntary organisations, and only making incidental reference to church based organisations (Garten, 1994:24). Histories of the Catholic Church also make little reference to the relationships between Catholic charities and colonial governments. General histories of the Catholic Church in Australia, such as Campion (1987) and O'Farrell (1985) do not tend to focus on social services but rather on broader political issues, the sociology of belief or the social impact of religious movements (Cleary, 1994: 52).

The general history of Catholic welfare endeavours has been neglected more than it should. Consequently, there has been a lack of analysis of the role of the Catholic Church in social welfare. Such an analysis is needed in the current climate of re-appraising the general arrangements between the state and voluntary organisations in welfare provision

(Hughes, 1998: 170 in Camilleri, 2000: 4)

Social welfare services have been organised through religious orders and lay workers in Australia since the 1830s. Many of these services provided material relief to the poor, and refuge, sustenance and support to those experiencing individual, family and social discord (Camilleri, 2000:2). The first conference of the St Vincent de Paul Society was at St Francis Church in Melbourne in 1854, followed by Perth in 1865 and NSW in 1880 (Manual of the Society of St Vincent de Paul, Australia, 1991). The Society visited families made destitute by the enormous social, economic and political changes wrought by the industrial revolution. It cared for Catholic women and children in 'desperate poverty' and provided simple shelter and food for destitute men (Dickey, 1987: 80).

With growing acceptance in the 1890s that poverty reflected social and economic conditions rather than the shortcomings of individuals, governments increasingly responded with a system combining government relief and private charity. From this time there was a growing awareness of the need for all human beings to have adequate access to housing, health care and education, irrespective of their income or social status (Usher, 2002:3). A number of religious congregations, whose primary concern was to provide education, health care and refuge for the working class poor, emerged in Australia (in particular the Josephite and Good Samaritan Sisters) during this time (Usher, 2002: 3).

The role played by the Catholic Welfare Bureaus which emerged in Australia in 1936 and 1941, can be described as 'substitutive' service delivery for families in crisis during and after the Great Depression and the Second World War (Gleeson: 2000:186). Under the patronage of the Catholic Church in the 1920's and 1930's, three Australian women, Norma Parker, Connie Moffot and Elaine Davidson were the first in Australia to undertake professional training in social work (Crawford \& Leitmann, 2001:44-45); Gleeson, 2000:189). This reflected recognition that charitable relief and the work of volunteers could not address the particular circumstances of many during that period and the conscious effort on the part of the Bishops to employ people with particular training and expertise (Gleeson: 2000). With Government policy firmly supporting the subsiding of private resources 
and providers, Church based agencies including Catholic services were well placed to develop their own innovative and diverse responses to emerging need and a national network of Catholic Welfare Bureaus was set up with the assistance of a Commonwealth subsidy. Increasingly these agencies attracted a range of commonwealth and state funding and were rapidly becoming the new face of Catholic welfare alongside the traditional religious orders and lay organisations (Smyth, 2001).

However, the increased diversity and scope of the sector frustrated the newly formed National Catholic Welfare Committee (NCWC) who considered it lacked the unity and leadership needed on social issues. By the late 1960s there was a concern that the Church might well be 'losing its influence and eventually its mission' (Smyth, 2001) in the new pluralist welfare state. The NCWC called for greater planning and cooperation in the Catholic welfare sector and greater recognition in the hierarchy of the role of the bureaus. In 1975 the National Catholic Social Welfare Commission was set up with an explicit mandate to strengthen the public advocacy voice of the Church on behalf of the poor and disadvantaged.

For church related agencies including Catholic Social Services, the early 1990's were a time of government funded pilot projects to address broad areas of need such as aged care, employment and disabilities. State and Federal governments offered funding to church related and other community agencies allowing considerable flexibility for the agency to develop innovative and effective models. Some Church providers however report that this period of innovation dried up in the latter part of the decade (Usher, 2003). Programs became institutionalised, and, in accordance with the competition policy of the time, were put out to tender. Church agencies, including the Catholic agencies, became concerned that market driven policies, the preoccupation of government with micro managing the agencies and the increasing dependence of church agencies on government funds for survival, would affect the capacity of the Church to carry out its social mission (Usher, 2003).

The tension experienced by the Church as it grapples with increased government funding opportunities alongside shrinking resources from within its own constituency is not explored here in any detail. It is identified, however, as a significant factor in the current tensions that exist between government and church related providers as the latter struggle to retain their autonomy from government.

Against this brief account of Catholic Social Teachings and an historical perspective which seeks to establish the Catholic Church's long tradition in responding to the disadvantaged, let us now turn to a recent study of pressures confronting Catholic agencies today in the pursuit of this mission.

\section{A Case Study of Catholic Organisations}

In 2002 the Australian Catholic University (Canberra) conducted research on the number, range and scope of Catholic agencies delivering social services and the pressures currently facing the sector. While this paper is specifically addressing the latter purpose of the study (pressures on the sector) the broader goals and methodology are briefly outlined here to provide the study context. The research design included: 
- A literature review to determine key issues in church based service delivery today;

- A survey sent to all Catholic agencies on existing mailing lists. Although the University did not have direct access to mailing lists there were around 180 surveys sent through Catholic Welfare Australia, 200 through the Australian Catholic Leaders of Religious Institutes, and 7 through the National Council of the St Vincent De Paul Society. The majority of Diocesan agencies (including almost all of the Centacares) returned surveys. Most of the 200 Religious congregations were of the view that they were not involved in social service activities and therefore did not return surveys. Unfortunately only three of the seven state offices of the St Vincent de Paul Societies returned surveys despite the best efforts of the National Office. One hundred and fifty three surveys were returned in all, including 45 from the Sydney Centacare group. Surveys provided data on 108 organisations, counting the Sydney Centacare group as one.

- In-depth interviews with Chief Executives of eight large Catholic organisations.

The study provided important information about the range and scope of Catholic agencies including the structure; legal status; accountability mechanisms; income and expenditure of the sector; number of staff employed on a full time / part time basis; women in management positions; volunteers; qualifications, professional representation and development needs of the sector; (Camilleri\& Winkworth, 2003). Challenges facing the sector were gathered through open-ended questions in the survey and the in depth interviews of Chief Executives (the latter also providing information about the scope and the historical context of services). The choice of interviewees was determined by their representativeness in terms of: agency auspice (Diocesan, Religious or Lay); the size of organisations ( small, medium, large); program type (eg: focus on children, youth aged, refugees). They were also selected because they had good knowledge of day to day operational challenges facing their organisations.

Around 239 responses were received to the open-ended question in the survey about the most important challenges facing their organisation in the next twelve months. These responses are set out below in figure 1 (fig1).

Fig 1: Challenges facing Catholic Social Welfare Organisations in the next 12 months ${ }^{2}$

\begin{tabular}{|l|r|r|}
\hline Challenges & Number & Percentage \\
\hline $\begin{array}{l}\text { Funding constraints affecting partnerships and the quality and } \\
\text { responsiveness of programs (topping up programs from own funds) }\end{array}$ & 74 & $31 \%$ \\
\hline $\begin{array}{l}\text { Increased accountability (Accreditation/reporting requirements/ } \\
\text { quality assurance/statutory demands) }\end{array}$ & 35 & $21 \%$ \\
\hline $\begin{array}{l}\text { Attracting and retaining adequate well trained staff (non } \\
\text { competitiveness of non profit sector with government) }\end{array}$ & 24 \\
\hline Continued alignment of staff with the mission of the church & 17 \\
\hline $\begin{array}{l}\text { Complexity of clients - combination of substance abuse, mental } \\
\text { illness and homelessness) }\end{array}$ & 6 & $10 \%$ \\
\hline Advocacy/lobbying - lack of resources & 40 & $7 \%$ \\
\hline Other & 239 & $16 \%$ \\
\hline Total & $100 \%$ \\
\hline
\end{tabular}


To add richness to data collected by survey, the above issues were raised in semi-structured interviews with organisational leaders. Five of the eight interviewees are quoted here because their interviews provided information of specific relevance to the questions about challenges and pressures. (The other interviewees provided qualitative data on the scope of services and historical context of services). The issues are discussed more fully below, particularly as these challenges are seen to impact on the mission of Catholic providers to provide responsive services to the newly emerging and long term disadvantaged and to fulfil its role as advocate for these groups.

\section{Funding constraints affecting partnerships and the quality and responsiveness of programs}

Thirty one percent of responses to the survey question about challenges facing the sector referred to funding constraints. While agencies recognise the very substantial increases in government funding over the past 20 years, highly specified contracts and greatly reduced Diocesan funding has had the effect of reducing autonomy to pursue agendas separate from the government policy of the day. With less scope to respond independently to pursue their substitutive role, Catholic organisations are also frustrated by an inability to achieve partnerships with government to determine spending priorities. Added to these frustrations is an increasing sense that the new accountability measures are diverting human and financial resources from direct service delivery.

\section{Reduced autonomy to pursue agendas separate from government policy - reduced innovation and responsiveness to local need}

The history of funding arrangements between Catholic agencies and governments is not well documented. Interviews with leaders of organisations however, provided context to concerns about the current arrangements and the impact they are having on the responsiveness of programs.

Interviewees referred to the need to 'top up' government funding out of church donations when government funding for programs with heavily specified outputs does not cover increased infrastructure costs (such as increased reporting requirements necessitating major upgrades to technology).

“The funding doesn't cover the infrastructure and we then have to use our own generated income which we should be using for creative, innovative things to top things up".Iv1 $1^{3}$

"In child welfare the price that is paid for the services after a lot of pushing over the years approximates $100 \%$ of the front recurrent costs, but it doesn't pick up the full back of house costs in terms of HR, administrative support; it doesn't pick up any costs at all for the physical plant or anything for IT infrastructure. So I think the full costs of those activities are grossly under represented in the funding rounds." Iv2

Interviewees also commented that they needed to be better prepared to access a more diverse range of funding sources such as business or philanthropic trusts so they can maintain their creative edge in local communities. 


\section{Lack of real partnerships with government to determine spending priorities}

Other leaders supported a view that contracts that are very highly specified are imposed on organisations and contribute to the sense that 'partnerships' are one sided. Funding and service agreements are imposed. As one interviewee remarked:

"I think this is where we have really got to call governments to task on what they call partnerships and say, look, its not just one way ...we don't just get an agreement and sign it. If you want a partnership we must have policy input as well.” Iv3

another said:

"When governments change their ideology and their approach to this work.... and to their sense of collaboration with us...there can be a sense that we are losing control over our mission...... The big threat is not the money so much... the government is giving us a lot of money to work with...it is the constraints that are put into our contracts that really make you sit up and think about whether you have become just an arm of government...it is not a question of being accountable...it is really a question of control" Iv1

\section{Accountability requirements diverting resources from direct service}

Twenty one per cent $(n=50)$ of responses to the survey question about challenges facing the sector referred to pressures resulting from increased reporting and quality assurance requirements. While there was a general support for measures that made service provision more efficient and protected service users from poor quality practices, a theme running through the data related to the difficulties faced by small organisations in particular, in putting in place infrastructures to enable compliance with reporting requirements. The inevitable outcome of increased requirements was a loss of direct service provision. The interviewees supported this:

"Dealing with very involved quality assurance requirements for government contracts is costly in time and money and takes away from direct service delivery. This has its own price because contracts expect us to keep it up to a high level.” Iv1

\section{Attracting and retaining adequate well trained staff.}

Thirty five survey responses (15\%) identified difficulties attracting and retaining appropriately qualified staff as a major challenge confronting their organisation. Key themes included the special difficulties experienced in rural areas $(n=7)$ and the perceived lack of competitiveness with government agencies in relation to pay and general working conditions.

\section{Continued alignment of staff with the mission of the Church - especially innovative outreach}

Around $10 \%$ of survey responses $(n=24)$ referred to the effect of an ageing Religious membership on the capacity of organisations to fulfil the Church's substitutive role. The interviewees further explained this: 
'The refugee issue is a good example. Clearly the government is not prepared to do it...so this leaves a huge gaping hole as far as sustenance and relief, accommodation, learning English and emergency assistance is concerned..... You'll often find it's the religious orders and the charities that come in and fill that gap....these groups have always been able to do things fairly cheaply'. Iv4

Whereas Religious have traditionally played an innovative outreach role with people on the margins such as remote Indigenous and refugees, the pay and working conditions of an increasingly professionalised workforce limit the capacity of Catholic agencies to undertake innovative roles.

"If you are relying on Religious Orders who are in many ways shoring up their operations rather than expanding into new areas, who is going to field responsibility for the new and growing and emerging areas in terms of geography and in terms of casework". Iv3

Other agencies on the other hand were quite clear that the changing membership of agencies was leading to a serious decline in staff who were aligned with the Social Teachings of the Church:

“..staff have become self serving rather than serving..” (survey respondent)

The commitment to mission and the reason why this commitment is integral to the distinctive role of church based agencies was articulated by one agency Chief Executive in the following way:

"Church based agencies have a great ability to be on the creative edge of community services and what the previous government [Kennett government] did by forcing us into that very dog eat dog mould was to deny themselves that creative component" Iv5

"We are still having to convince them [government] that your mission and your values and your charism and your history all influence the way you do things in the community and that we are better placed to know how people are feeling and where communities are. I think there is still a long road to go and it will require a major cultural change.” Iv5

"I think the adherence to a mission and vision draws in creative people who are looking beyond mere recompense. An awful lot of staff don't do it for the money...I think there is a link between the fidelity to a vision for people in the community and the drawing in of creative people." Iv5

\section{Working within a system that fails to address the increasing complexity of clients}

Seventeen responses (7\%) specifically mentioned increasingly challenging client groups. This subject was fleshed out with interview respondents who without exception identified this as a serious challenge to all community welfare agencies. All interviewees referred to a mix of mental health, drug and alcohol and homelessness issues. A concern running through the data was that governments and community agencies were not successfully addressing these complex issues in partnership so funding contracts continued to be one dimensional and out of touch. An interviewee commented: 
"You might want to work on financial issues but first you have to address drug and alcohol issues. You might want to work on child and family issues but unless you can get the immediacy of say an addiction like heroin out of the way its just going to be there all the way. Iv3

The majority of respondents and interviewees also mentioned the interface of homelessness and mental illness as a challenge that cannot be addressed effectively without a more coordinated community approach:

"People who are homeless and are using are more desperate and tend to stand over people. Some of our older clients are being pushed out by the younger ones who are just so much more aggressive. ...Some have a mental illness..... We've had ten to 15 years of deinstitutionalisation...I fear we are going to see a reinstitutionalisation of those people into homeless agencies and prisons unless there is a significant build up of supports within the community." Iv3

\section{Advocacy and the Prophetic Voice of the Church - 'biting the hand that feeds them' (ACSWC, 2000:18)}

One of the issues raised by the Catholic Social Welfare Commission in a paper prepared for the Bishops Ad Hoc Committee for Pastoral Discussion in 2000 was the concern that contractual arrangements requiring agencies to seek approval before releasing public comment would undermine the maintenance of theological vision and 'preservation of the Church's prophetic voice' (ACSWC, 2000:19). This concern was particularly strong in relation to employment contracts. It was reiterated strongly by the same interviewee:

"to (maintain) the prophetic voice of the Church, its social justice voice...is to my mind the biggest challenge of this modern welfare state where we are all kind of melted down into these amorphous provider groups that are fairly grey and indistinguishable...” Iv3

Although only three percent $(n=6)$ of survey respondents mentioned this issue it is worthy of a discussion here because it tends to dominate the literature on issues confronting church related organisations (Mendes, 2003: 155-168; ASCWC, 2000) and all organisational leaders interviewed in the study referred to it.

The study determined that Catholic organisations placed a high priority on the employment of staff in advocacy and policy positions. All responses through the survey, which identified advocacy as a challenge, however, referred only to the need to improve skills in this area. Interviewees foresaw possible challenges to the prophetic voice of the church (Australian Catholic Social Welfare Commission, 2000: 8) but the general feeling was that the fear of consequences was probably greater than the reality. Some interviewees were very clear that the challenge for Catholic organisations was in finding constructive ways to use its voice to bring about improved services for people who do not have a voice. The threat of being de funded was a very real one 'because federal ministers don't see a role for direct criticism' (Iv3). Advocacy agencies need to exercise skill and diplomacy to affect change.

“...I suppose it throws up a challenge for those who want to be involved in advocacy.... if you want to stay in the game and be heard with the incumbents, whoever they are. That's difficult too because people say 'where is the voice of 
the Church in all this?' So you can be heard and be sidelined or you can get in there and have influence and not be heard in the broader community. I guess both strategies are important. Part of advocacy and the voice of the Church is actually taking a public leadership role in the community and its not just about influencing politicians its about bringing the Church and Church leadership and congregations and the broader public with you on issues of social justice.' Iv3

\section{Conclusion}

The application of market principles to church related welfare providers through funding agreements clearly poses threats and challenges to the maintenance of traditional roles such as the pioneering of new services and the provision of assistance

where governments are unable or unwilling to assist. Additional concerns not addressed here but deserving of further consideration include: maintaining the broader pastoral identity of the church in a time of shrinking resources; meeting the needs of local communities when public funding is withdrawn; providing security of tenure beyond the term of a government funding agreement for those who work on specific church related programs (ACSWC, 2000).

This paper examines the wider context in which church related and other not for profit agencies are delivering human services today. A consideration of Catholic Social Teachings and the church's history of care and advocacy provide a backdrop to the findings of a small research study on Catholic service delivery in Australia, particularly the challenges facing the sector. The paper seeks to demonstrate that the Church and its social service agencies are driven by social teachings which promote the dignity of the individual, humane services for the poor and the imperative to speak out publicly on areas of unmet human need. It also supports previous studies that the new contractual environment is perceived as placing considerable strain on the traditional ethos of these services.

Although this paper only reports on one part of the sector, the other large church groups: Anglicans and Uniting Churches, the Salvation Army as well as the Catholic Church, provide the majority of services from non government agencies to the Australian community. A greater appreciation is needed of the distinctive contribution of these groups and what they have to offer in service delivery and as contributors to the social policy discourse. 


\section{References}

Brown, K., Kenny, S., Turner, B.S., with Price, J.K. (2000) Rhetorics of Welfare: Uncertainty, Choice and Voluntary Associations, St. Martins Press, Inc.

Cnaan, R. \& Boddie, S. (2002) 'Charitable choice and church related welfare' Social Work, Vol 47, No. 3, New York, p224-235

Camilleri, P. (2000) A Partnership in Research-Australian Catholic University and Centacare Paper presented to the Torch Bearers National Centacare Congress, September 12-15, 2000

Camilleri, P. \& Winkworth, G. (2003) Disparate and Diverse: Mapping Catholic Social Services in Australia, Canberra, Australian Catholic University

Campion, E. (1987) Australian Catholics, Ringwood Victoria, Australia

Catholic Social Welfare Commission (2000) Theological Aspects and Practicalities of Church Involvement in Government Funded Welfare Services, Paper prepared for the Bishop's Ad Hoc Committee for Pastoral Discussion

Cleary, M. (1994) 'Management Dilemmas Facing Catholic Human Service (Health, Education and Welfare) Organisations in Australia' Edited Roselyn Melville, Third Sector Welfare: The Industry Commission's Inquiry and the Future of Non Government Organisations, Sydney Seminar, Discussion Paper No. 5

Crawford \& Leitmann (2001) 'The Midwifery of Power? Reflections on the Development of Professional Social Work in Western Australia' Australian Social Work, Vol 54, No.3 pp43-54

Dickey, B. (1987) No Charity There: A Short History of Welfare in Australia Allen \& Unwin Australia, Pty, Ltd.

Ferguson, J. (2002) Challenges to Church Involvement in the Provision of Government Funded Employment Services in a Competitive Market Environment Catholic Welfare Australia, unpublished paper

Garten, S. (1994) in Wearing, M. \& Berreen, R. (eds) Welfare and Social Policy in Australia, Harcourt Brace, Sydney, Ch 2

Gleeson, D. J. (2000) 'Professional Social Workers and Welfare Bureaus: The Origins of Australian Catholic Social Work' The Australian Catholic Record, April, 2000, Vol 77, No.2

Glenn, L.C. (2000) “The Ambiguous Embrace: Government and Church related Schools and Social Agencies Princeton University Press - Foreword

Graycar, A.,Horsburgh, M. \& Wyndham, D. (1988) 'Welfare' D. H. Borchardt and V. Crittenden (Eds.), Australians: A Guide to Sources Broadway, NSW: Fairfax, Syme and Weldon Associates

Ife, J. (1997) Rethinking Social Work: Towards Critical Practice, Addison, Wesley, Longman, Australia, Sth Melbourne.

Industry Commission (1995) Charitable Organisations in Australia, Report No. 45, 16 June, 1995

McDonald, J. (2002) 'Contestability and social justice: The limits of competitive tendering of welfare services’ Australian Social Work, June 2002, Vol.55, No. 2 
Mendes, P. (2003) Australia's Welfare Wars: The Players, the Politics and the Ideologies UNSW Press, Ltd.

Neville, A. (2000) 'The Implementation of Competitive Tendering', Just Policy, No 18, April 2000

O'Farrell, P. (1985) The Catholic Church and Community: An Australian History UNSW Press, Kensington

Rogan, L. (1997) Keeping Sight of the Goal: 'The Limits of Contracts and Competition in Community Services' ACOSS Section 5, Contracting Out: Contract and Tendering-A Hierarchy of Considerations

Rawsthorne, M (2003) 'Contracting -the impact on non government organisations' paper presented to Australian Social Policy Conference, 2003. UNSW Social Policy Research Centre

Smyth, P. (2001) 'The Church's Social Mission in Australia' paper presented at The State and Civil Society in the Delivery of Social Services: The Catholic Church in Australia, 2 day workshop, 2001, Catholic Welfare Australia

The Society of St Vincent de Paul (1991) Manual of the Society of St Vincent de Paul Australia, National Council of Australia, Darlinghurst

Usher, J (2002) ‘Catholic Welfare Service: The World:The Kingdom’ A Presentation to Staff of Centacare Canberra- Goulbourn, May, 2002

Usher, J (2003) Unpublished transcript of interview for Mapping Catholic Social Services, Australian Catholic University, 2003

Wearing, M., Smyth, P. \& Sotori, M. (1999) 'Resisting the Global, Remaking the Social?; Framing Ethical Partnerships in Contracted Human Services', refereed paper from Third Sector and State Partnerships Conference, Deakin University.

Wuthnow, R. Hodgkinson, V. \& Associates (1990) 'Faith and Philanthropy in America: Exploring the Role of Religion in America's Voluntary Sector' Jossey, Bass Inc. Publishers

http://www.catholicwelfare.com.au/about_us/).

(http://www.css.org.au/about)

\section{Footnotes}

1. This description excludes the Red Cross which was identified as the second largest provider. The nine agencies were: Salvation Army Southern Command, Salvation Army Northern Command, World Vision of Australia, Wesley Mission Sydney, Anglican Retirement Villages, Baptist Community Services NSW and ACT, Anglican Home Mission Society, Churches of Christ Care, The Brotherhood of St Laurence.

2. Results rounded to the nearest decimal point

3. Interviewees are identified numerically to preserve confidentiality 